the large number of laboratories, hospitals and experimental farms in Great Britain involved in nutritional studies in the widest sense. There are many actual and potential workers in this field who would enthusiastically welcome some recognized centre to which they could turn for advice about what to do next and how to do it, in the best interests of the nation at war. At meetings of scientific societies it happens over and over again that workers discover others to be investigating problems allied to, or even the same as, those on which they have themselves been working, independently and, as they thought, solely. How much better had contact been made before the work was well in hand.

We have suggested above that co-ordination, if it is to be effective, must include several major State Departments, besides the organizations specifically devoted to research, both outside and inside industry. This appears to be generally recognized, but it has led to a confusion of thought that, if not removed, might have unpleasant or even disastrous consequences. It is a fundamental principle in a country organized as a parliamentary democracy that all questions of major policy, affecting the everyday life and health of the people, must be decided by that people, speaking and acting through its constitutionally elected representatives, the Government and the Cabinet. Nor can there be the slightest doubt that decisions about the people's food, what it shall be, how it shall be distributed and what it shall cost in terms of real wages, are decisions on a matter of major policy. It follows inevitably that food policy must be determined by Parliament. To suggest that an ad hoc organization of experts shall make decisions on such matters of policy is not merely to propose a restriction on the legitimate rights of the ordinary sitizen, but also to condone the introduction of the thin end of the wedge of the totalitarian State. It must be vigorously opposed by all men of democratic goodwill, no less by those who support the formation of a new Nutrition Council than by those who oppose it. The fundamental business of such a Council would be to bring together existing knowledge and disseminate it properly, to co-ordinate present investigations, and to map out future research. Under the first of these heads, it may be remarked, one of the most important tasks is to forward that knowledge directly to those who have to control, on behalf of the community, the country's food policy. General educational propaganda can probably best be left to other bodies, especially to those more closely linked with local government activities, a procedure that is rapidly extending in both Canada and the United States. One letter in The Times argues that the suggested work of a Nutrition Council is the function of the Cabinet's Committee on Food Policy. Surely this is but a further instance of the confusion to which we have just referred-quite apart from the fact that this Committee is concerned with transmitting advice and information only in one direction, upwards, and has no part to play in the organization of actual research.

Thus, decisions on food policy are, as Sir John Orr has also emphasized, matters for Parliament and the
Government. The Nutrition Council as such should have nothing to do directly with food policy, but indirectly it could vitally affect policy. Its task would be, by its contact with responsible Ministers and administrators, to make available to them as rapidly as possible those established results of nutritional research on which, and on which alone, a wise and lasting policy, one that makes for health in the national sphere and peace in the international sphere, must be based. The conditions of war, despite all its handicaps and horrors, make advances in nutritional knowledge more rapid in many directions even than those that have characterized the last three decades or so. The potentialities can only be exploited to the full if all available knowledge and skill, from many scientific disciplines, can be brought to bear with speed and efficiency. A properly constituted Nutrition Council would be a valuable, and may be an indispensable, means to this end.

\section{EDUCATION AND LEADERSHIP IN THE WOMEN'S SERVICES}

$\mathrm{T}$ HE report of the Committee on Amenities and Welfare Conditions in the Three Women's Services* merits wide publicity. A thorough and searching inquiry provides the basis for a balanced and reassuring report which effectively disposes of the vague and sweeping charges of immorality. Some unpleasant experiences in the Services are frankly acknowledged, and the report shows no lack of constructive criticism or, on the other hand, of appreciation for what is and always has been good in the three Services.

Healthy realism and common sense pervade the report, which does not conceal the fact that mistakes in administration have been made, and that the biggest problem in the Women's Services, as elsewhere, is not that arising out of hardships or rough conditions, which are instinctively recognized as part and parcel of the War, but out of boredom in the non-operational units. There lies the main danger to morale both in the Services or in the civil population, and it is of the utmost importance that due attention should be given to this question at an early stage.

Taking the view that the essentials for welfare are definite minimum standards of accommodation, warmth, food, medical attention and hygiene; good leadership by efficient and understanding officers; full utilization of individual capacity so far as the exigencies of the Services permit; and encouragement from home and from the general public, the Committee, while not minimizing the part which the Services have to play, shows unmistakably that the public must bear some responsibility itself in this matter of welfare. The part which the officer can play is rightly stressed. An officer whose first care is her platoon or company can, by her zeal, unselfish. ness and good sense, make the roughest conditions acceptable, while if an officer is indifferent or unsympathetic, the tone deteriorates and complaints

- Report of the Committee on Amenities and Welfare Conditions in the Three Women's Services. (Cmd. 6384.) Pp. 58. (London: H.M. Stationery Office, 1942.) 18. net. 
mount up even in the best and most modern of accommodation.

With much of the detail of this report scientific workers have little direct concern, though the sanity and foresight of many of its comments, for example, in regard to cooking and the raising of standards, and the recruitment of officers, are of at least passing interest, but the invigorating vision of opportunity which characterizes the sections of the report dealing with education and with the future gives these sections at least outstanding claims on their attention. The Cormmittee frankly recognizes that the major problem which lies ahead of society is how to reconcile in a highly mechanized world the quality and free expression of the individual within the framework of the co-operative State The middle path has to be found along which organization and individuality can walk together hand in hand, and though the Committee recognizes that in the three Services young women have been brought together, without distinction of class, to share a common life while fulfilling a common duty to their country, it is felt that a great opportunity is being missed in another direction. Service life with its common tasks, common duties and common amusements is a training place in the subordination of the individual to the whole; but the whole can have no richness unless interpenetrated by the quality and variety of the individual human beings who compose it.

The mingling of all classes in the present national effort is unquestionably a situation full of promise for the future, and from this point of view the camps represent a great social experiment no less than a great military effort. Experiences previously unknown on one side or the other have been exchanged and shared. Camp life, too, is a great discipline in give and take, and in sharing the ups and downs of a common existence. From the soil thus ploughed a rich harvest may be gathered if the seed is first sown by $\mathbf{a}$ wise and skilful sower.

This is the point of view from which the Committee approaches the question of education, and while it is clear that so far as facilities and organization are concerned, the authorities provide generously for any educational demand made on them by the men and women of the Services, it is idle to pretend that the demand is in any respect equal to the possible supply. Education as a great adventure, as an adventure which makes life infinitely more attractive and exciting, is an appeal which falls too often on uncomprehending ears. It is a melancholy reflection, the report observes, on the educational failures of the last twenty-five years, that many young people refuse to use their minds at all outside working hours, and their only cry is for amusement which can be produced without any demand on their initiative, industry or intelligence.

The Committee considers that youth cannot be held responsible for this dangerous and disturbing position, which the difficulties of Service education in the present War have thrown into high relief. In pre-war days, leadership failed a young people who still depend more than they realize on the outlook of their elders, and who were left by the latter without any heroic appeal either to their imagination or sense of duty. We owe them what compensation in us lies for the state of the world as it is to-day, and the Committee refuses to acquiesce in a defeatist attitude about a matter so intimately concerned with the great issues of the present and future $A$ number of proposals for stimulating interest are made, the main recommendation being the appointment of an adequate number of women of suitable rank and relevant experience as education officers in the field to ascertain the outlook and requirements of the rank and file and to stimulate interest among the officers of the Women's Forces. It is recommended further that the curricula of the officers' training courses and of refresher courses should be placed on a broader basis; that the Army Bureau of Current Affairs scheme should be invariably applied in the A.T.S. and should be extended to the W.A.A.F. and the W.R.N.S. ; that crafts should be encouraged for those whose tastes lie in practical directions, and that the Council for the Encouragement of Music and the Arts should be asked to co-operate in the general development of music, drama and the arts.

These recommendations are clearly to be justified on the ground of their immediate contribution to the morale and efficiency of the Women's Services. Their bearing on the welfare of the young womanhood of Great Britain after the War and on the future of the Women's Services, so brilliantly discussed in the concluding section of the report, is no less obvious. The unparalleled opportunity of education in citizenship and good living is recognized. There are things to unlearn and false idols to dethrone, but the chance if seized may sweep the whole national existence from banks and shallows into the great waters of the main.

Whether we look to this educational aspect or to the new riches which the country has found in this great development of skilled capacity in the Women's Services and elsewhere through the War, the question of the future of the Women's Services cannot but be considered. That indeed lay outside the terms of reference of the Markham Committee, though it is clear that the uncertainty is affecting the recruiting of young women of the professional classes. Moreover, no thoughtful observer can be blind to the waste which would be involved in any immediate break up of the Women's Services and the abrupt termination of their remarkable contribution when the cease fire sounds. Effort and sacrifice no less than time and worry went to their creation. Their efficiency increases daily, and it is only right that the question whether the State has no use for them after the War should be frankly faced.

Demobilization of a nation in arms and remobilization for the campaigns of peace should clearly, when the time comes, take place with due regard both to the tasks ahead and the personnel available. The Markham Committee is convinced that in the Women's Services the nation possesses an instrument of great potential usefulness, and suggests that when their present duties come to an end, their training and experience make them specially fitted for service in the field of European reconstruction. Detachments of the Women's Services would, they consider, be 
admirably fitted to share in the duties of the technical staffs which will be required throughout Europe, both for administration and relief, to meet the needs of the liberated populations. The various missions concerned with food and clothing, housing and medical assistance, which must clearly function as a first step on the Continent, for a time can obviously only function on a military basis and under the protection of the armed forces engaged in the restoration of order. Much of the work to be done is, moreover, work in which the co-operation of women is not only desirable but also essential, and that co-operation could be achieved rapidly and simply through the organization of the auxiliaries for foreign service.

Besides such specific duties as those of clerks, cooks, drivers and orderlies, there will be plenty of administrative tasks for officers capable of handling the problems of want and suffering which the liberated countries will present. While, however, employment for the time being on the Continent-for which, as the report notes, a precedent already exists-would ease the demobilization of the Women's Services and the return of its personnel to civil life, the Committee considers that the moral effect of this proposal is far more important than any other consideration. "To associate women with the task of reconstruction in Europe, to call upon them to share in a work of healing and mercy, would be not only to bring their war duties to a noble conclusion but to open a new chapter in international relationships of high value for the future."

There can be little doubt that volunteers would be forthcoming from all the Services for any feasible scheme on these lines, and that the auxiliaries would throw themselves into the work and adventure of peace with the same enthusiasm as they show to-day in the work and adventure of war. Knowledge and experience gained in this way could scarcely fail to be of value to themselves and others in remodelling a world in which all are groping towards some practical expression of the truth that we are members one of another, united by ties of past suffering and a larger hope for the future. There is wisdom as well as vision in these suggestions of the report, and they have their own special implications for all who are concerned with the wide problems of reconstruction, among which that of education adequate to meet the needs of a new world is one of the foremost and most urgent.

\section{AUSTERITY THINKING}

Sumner To-day

Selected Essays of William Graham Sumner, with Comments by American Leaders. Edited by Prof. Maurice R. Davie. Pp. xxvi+194. (New Haven, Conn.: Yale University Press; London: Oxford University Press, 1940.) 15s. 6d. net.

THE name of William Graham Sumner (18401910 ) is so comparatively little known in Great Britain, except perhaps as the author of "Folkways", that it comes as something of a surprise to discover that there is in the United States a Sumner Club which has sponsored the publication of this centenary volume "as a means for stimulating the scientific study of society". The book itself consists of reprints of some of Sumner's essays, lectures, and extracts from his works together with comments by so-called "American leaders".

The essays have as a whole an astringent flavour and are the more challenging as coming from the pen of one who was mistrustful of democracy in its heydry, and a robust champion of the individualist point of view, a "hard-headed realist" as he has been called by a recent writer, "the father of all the debunkers". He tilts at what he considers the "sbsurd effort to make the world over", contending that the social order is fixed by laws of Nature which men must in the long run obey, their only hope of better and happier living lying in greater industry, self-denial and temperance. There is no short-cut to prosperity and no way by which men can be saved from the consequences of their own failure. He was disdainful of much of the teaching of his day : robust in his repudiation of many fashionable doctrines, and insistent above all on the necessity for dispassionate examination of social issues and problems and the separation of the scientific and emotional attitudes to these problems.

We have only recently entered upon a period in which it is possible for the sociologist to be educated as such, and Sumner went to Europe as a young man to study for the Christian ministry. From the Germans he apparently learned much through what he calls their "nobly scientific" approach to the study of the Bible. But at Oxford he gained more from his fellow students than from his teachers, and acquired such a taste for social and political inquiry that three years after his ordination in 1869 he was actually appointed to the chair of political and social science at Yale. There he wielded considerable influence, interesting his students in social study, taking over the Spencerian doctrine of social forces and social laws, and preaching the necessity both for studying and conforming to them. The word 'preaching' is used advisedly; for Sumner was nothing if not dogmatic, and (despite himself) as much moralist as scientist. There is little doubt, however, that he served a useful function in his day, shaking men out of their complacency, demanding careful scrutiny of measures proposed for the betterment of human affairs; pessimistic perhaps as to their consummation, but anxious only to know the truth-in the belief that the truth alone, however unpalatable, could set men free.

To Sumner, if the notion of equality was suspect, liberty as interpreted at the end of last century was no less so, and justice not by any means to be achieved along the lines of the panacea so frequently advocated -that of a fresh transfer of wealth from one section of the community to another. His plea for "The Forgotten Man", for example, is made in favour of the uncomplaining millions, the victims as he calls them of the reformer, the social speculator and the philanthropist-the small men of the lower middle class to whose misfortunes attention is seldom given, and who are called on from their meagre living to share the burden of the support of the socially inadequate. In a free democracy all propositions to do something for the working classes have, we are told, an air of patronage and superiority which are out of place; the capital needed for the support of social failures is inevitably diverted from alternative and better uses, and liberty must take the form of industrial competition. 